\title{
Incumbents' use of pre-entry alliances before expansion into new technical subfields of an industry
}

\author{
Will Mitchell* and Kulwant Singh
}

University of Michigan, Ann Arbor, MI, USA

Received July 1990, final version received January 1991

\begin{abstract}
Industry incumbents frequently delay entry into emerging technical subfields, fearing product cannibalization and uncertain investment, and enter only after technical and market uncertainties have subsided. We predict that many incumbents, particularly stronger firms, will participate in alliances with other firms before their standalone entry. The alliances will be used to realize part of the value of specialized assets and to gain information about the emerging products and markets. We support the predictions with evidence from the U.S. market of the medical diagnostic imaging industry.
\end{abstract}

\section{Introduction}

In most product-based industries, the strongest competitive factor is product change [Schumpeter (1942); Nelson and Winter (1982)]. For firms in these industries, the key strategic issues are likely to be innovation and appropriating the returns from innovation [Teece (1986)], rather than price and quantity determination for a stable set of products. When a new technical subfield of an industry emerges, a firm operating in the industry must decide whether to introduce the new products, when to do so, how to acquire necessary knowledge, and how to lever the value of its existing assets in the new segment of the industry [Mitchell (1989)]. ${ }^{1}$

Correspondence to: Will Mitchell, University of Michigan, School of Business, Ann Arbor, MI 48109-1234, U.S.A.

*We would like to thank two anonymous referees for their many useful suggestions.

${ }^{1}$ We define an industry as a group of firms which manufacture products having "reasonable interchangability of use or cross elasticity of demand' [U.S. Supreme Court (1964, p. 76)]. This definition encompasses both direct substitutes and products which are not direct substitutes but which cnjoy purchase complementarity, that is, are linked in buying habits. The 'Brown Shoe' Supreme Court decision cited above used the latter criterion to find that men's shoes and women's shoes were in the same market. Similarly, magnetic resonance and $x$-ray imaging equipment are not exhaustive substitutes in use, but a buyer's experience with $x$-ray equipment is likely to influence the decision to purchase magnetic resonance imaging devices. A technical subfield of an industry [Mitchell (1989)] is a set of products which draw on a distinct knowledge base [Nelson and Winter (1982)]. 
Many studies have investigated the incentives that drive industry leaders to invest in product development and to vary the introduction time of new products resulting from such development. ${ }^{2}$ The general conclusions are that industry leaders have incentives to invest in major product development, may or may not invest as much as newcomers, and are likely to introduce new goods only after industry entrants. Although the thcoretical studies have succeeded in explaining some empirical phenomena, they have either contradicted or ignored others. The problems have been caused, in part, by most researchers' having conditioned their conclusions on fairly restrictive circumstances - difficult-to-imitate innovation, industries made up of similar firms, and quantifiable risk - so that the applicability of findings has been limited. In addition, only recently have researchers begun to study the implications of different interorganizational alliances used to acquire the know-how needed to take part in innovation-based competition and realize the value of existing assets when applied to new uses.

In this paper, we examine interorganizational alliances used by incumbents of the diagnostic imaging industry to expand into new technical subfields of the industry. The context of the study is an industry in which core product innovation tends to be major, but necessary supporting assets retain their value through generational changes. In the context of the Abernathy and Clark (1985) transilience map, such cases may be referred to as lowtransilience innovation, that is, core product changes which do not 'leap across' [Kirkpatrick (1983, p. 1371)] existing supporting assets. Common examples of such innovation are found in the consumer electronics sector. VCRs, for instance, differ significantly from tclcvisions, yet their successful commercialization required similar supporting assets, such as distribution systems designed for consumer electronics, reputations with buyers of electronic products, and the ability to carry out incremental R\&D.

The literature on diversification [Rumelt (1974), Ramanujam and Varadarajan (1989)], competitive strategy [Hitt and Ireland (1985)] and technological innovation [Dasgupta and Stiglitz (1980), Reinganum (1983)] suggest that incumbents should expand into related emerging subfields to exploit their resources. Doing so rapidly would provide a competitive advantage, and entering on a standalone basis would allow the appropriation of earnings from the venture. We argue that industry, firm, and technological conditions frequently dictate that incumbents adopt a more cautious approach to entry into subfields within the industry.

When an industry incumbent enters a new product area in which many supporting assets retain their value, the firm will often limit its investment exposure and expand its knowledge sources by using alliances with other

\footnotetext{
${ }^{2}$ See, for instance, Dasgupta and Stiglitz (1980), Gilbert and Newberry (1982), Reinganum (1983), Katz and Shapiro (1987), Lieberman and Montgomery (1988), and Conner (1988).
} 
firms before undertaking standalone entry. We identify different types of alliances and predict that the incentives to use alliances will vary with the current strength of the entrant and the stage of development of the product. The degree to which new supporting assets are required for success in the new technical subfield will also influence the tendency to use pre-entry alliances. In addition, we test the prediction that the tendency to usc alliances will vary systematically with the nationality of firm ownership.

We test our predictions, finding support for most, by examining participation in pre-entry alliances by 87 incumbents of U.S. markets of the medical diagnostic imaging industry before the incumbents' expansion into five new technical subfields of the industry. This industry consists of firms which manufacture devices used by physicians and other health care workers to obtain information about the internal functioning of the human body. The industry is suited for this study because it provides a relatively large sample from a diverse set of firms over a 30 year period, during which technical and market change and incumbent expansion have been common. The results can be applied to a wide set of industries, with implications for competition in industries facing the threat of emerging technological, market and competitive challenges.

\section{Background}

\subsection{Imitability, different firms, and technical uncertainty}

Few real cases of product-change competition confirm to the restrictive conditions of narrow theoretical treatments. Contrary to assumptions, most innovation is imitable within reasonable horizons [Mansfield et al. (1981), Levin et al. (1988)], most industries contain very different sorts of firms [Nelson and Winter (1982), Teece (1986), Barney (1986), Mitchell (1989)], and most major innovation is uncertain rather than risky, in Knight's (1922) sense of uncertainty as unknowing and risk as measurable variation. Although technical change may eventually take place along an identifiable trajectory [Nelson and Winter (1982), Dosi (1982)], early designs will be varied [Abernathy and Utterback (1978)] and the future development path not at all apparent. In such conditions, the menu of options from which an industry leader must formulate its innovation strategy contains more than investment and timing choices. A firm must also decide what products to invest in, where to acquire know-how for the product development, and how to acquire the knowledge.

Underlying the complexity of the strategic options is the risk of investing in transaction specific assets that turn out to have little value. Williamson $(1975,1985)$ argued that a firm will benefit by integrating valuable idiosyncratic assets. The same forces, however, discourage firms from investing in 
special-purpose technology during early development stages, when the value of such investment is highly uncertain [Williamson (1988)]. Moreover, given organizational tendencies to build routines around past choices [Hannan and Freeman (1977, 1984), Nelson and Winter (1982)], there is a significant probability that by investing early in a development stage, a firm will lock itself onto an inferior trajcctory [Licberman and Montgomery (1988)].

Although all entrants face uncertainty, the problem is particularly acute for industry leaders. Not only might an incumbent lose its new investments, it might damage past investments as well, because successful new goods may cut into sales of existing products [Reinganum (1983, 1985), Tushman and Anderson (1986), Lieberman and Montgomery (1988)]. Moreover, introducing new goods that fail may damage an incumbent's reputation [Leonard-Barton (1985)] or otherwise reduce the value of the supporting assets which support existing products [Abernathy and Clark (1985), Mitchell (1989), Mitchell and Singh (1990)]. As a result, empirical research has found that major innovations tend to be introduced by industry newcomers [Jewkes et al. (1958), Cooper and Schendel (1976), Tushman and Anderson (1986)].

But if an innovation is successful, industry leaders must respond or lose ground to the newcomers. In some cases, incumbents choose not to respond and are replaced, particularly when a new product not only substitutes for the old good, but requires a broad new set of supporting assets, which Abernathy and Clark (1985) refer to as high-transilience innovation, that is, core product changes which do 'leap across' existing supporting assets. ${ }^{3}$ When supporting assets retain their value, incumbents tend to respond and often continue to dominate the evolving industry; but, even in such cases, an incumbent must make entry strategy choices.

Although an incumbent would like to delay its response until the direction and success of the technical trajectory is apparent, it may not be able to do so. Strong potential competitors or strong potential for quick replacement of the old products by the new may force it to enter before technical and market uncertainties have subsided [Mitchell (1989, 1991a)]. For many goods, technical participation at later stages requires a cumulative knowledge built up by participating in earlier phases [Mowery (1983), Dosi (1988)]. Therefore, an incumbent often needs to position itself during early uncertainty, in order to jump onto a technological trajectory that will only later be defined.

Even if a firm enters a new field several years after it first emerges, many uncertainties will remain. The firm is unlikely to introduce a product

\footnotetext{
${ }^{3}$ This is consistent with Reinganum's (1985) prediction that leading firms will be replaced by innovative newcomers, suggesting that the context for such theoretical constructions may be restricted to cases in which both core products and supporting assets are replaced by innovations.
} 
identical to those already in the market, so that it will be faced with the uncertainty of innovation. And, of at least as much importance, it faces the uncertainty of acquiring the knowledge required to compete in a new field, and incorporating that knowledge into organizational routines.

In order to position itself, a firm must acquire know-how relevant to the emerging product which will often require contact with other firms, because of the need to put together many complementary assets, skills and technologies [Phillips (1966), Jorde and Teece (1989)]. A firm may possess the seeds of an innovation, while lacking the complementary capabilities necessary to refine the product beyond the prototype stage, and to bring it to market at competitive prices [Ford (1985)]. The methods that a firm uses to interact with other organizations will influence the knowledge it is able to acquire, and how much of the value of this know-how it will be able to realize [Teece (1981), Hamilton (1985), Harrigan (1985a)].

There are many means by which firms can acquire information. Hands off means include searching published material and reverse engineering. More often, knowledge will be acquired through hands on individual or organizational contact. Individual contact includes key people in academe, research laboratories or competitor firms. Organizational contact can take place on a markets to hierarchies continuum, with short term contracts at the markets end and integration through acquiring part or all of a firm at the hierarchies end [Mitchell (1991b)].

\subsection{Interorganizational options}

Interorganizational collaboration is increasingly being recognized as offering a middle path between the markets and hierarchies alternatives of organizational contact. $^{4}$ Rationales for collaborative ventures include spreading risk, increasing market power, sharing resources, and gaining organizational learning [Pfeffer and Nowak (1976), Powell (1990), Contractor and Lorange (1988)]. Alliances may serve as surrogates for more permanent links, sometimes allowing organizations to obtain the desired benefits of collaboration without the added costs of governance [Williamson (1975)].

Industry incumbents seeking to expand may be attracted to interorganizational alliances in order to gain access to market knowledge and core technical know-how. ${ }^{5}$ Acquiring market and technical knowledge via an alliance rather than through standalone methods will frequently limit an incumbent's investments in transaction specific assets which may later turn out to be valueless [Williamson (1988), Kogut (1988)]. Different forms of

\footnotetext{
${ }^{4}$ See, for instance, Pointer et al. (1988), Jorde and Teece (1989), Astley and Brahm (1989), Hamel el al. (1989), and Powell (1990).

${ }^{5}$ See Harrigan (1985b, 1987), Gross and Neuman (1988), Clarke and Brennan (1988), and Teece et al. (1988).
} 
alliances - ranging from minority equity holdings to components manufacture to distribution of another firm's products - represent a menu of collaborative modes which provide varying degrees of market and technical knowledge.

Interorganizational options may also provide means of realizing the value of an asset without investing in all necessary supporting assets. If an industry incumbent distributes another firm's products, for instance, the incumbent not only gains knowledge about the market for the products, but gains part of the profits accruing to the goods. Such an option may involve less risk, at least in the short term, than developing internal manufacturing capabilities.

However, alliances only rarely provide long term methods of market participation. Governance and technical problems cause most to break down within a few years [Harrigan (1985b)]. In some cases, the alliance breaks down because it cannot successfully produce or distribute goods and is dissolved. In other cases, the alliance succeeds in producing a successful good, but breaks down due to managerial disagreement, legal problems, and diverging aims, so that one of the parties lakes over the venture. Kogut (1989), for instance, found a $70 \%$ termination rate among 92 U.S.-based manufacturing alliances, with about $40 \%$ of the terminations occurring through dissolution of the venture and the remainder through acquisition. ${ }^{6}$ Thus, although a pre-entry alliance may provide lower risk than independent participation, even a successful alliance will usually only be a precursor to standalone entry.

In this study, we examine the use of pre-entry alliances by industry incumbents which later undertook standalone entry into emerging technical subfields of their industry. In order to provide a context for the study, we next describe the empirical base. We then present specific hypotheses and describe the analysis.

\section{Medical diagnostic imaging industry}

\subsection{Products}

This study is conducted in the context of technical subfields of the medical diagnostic imaging industry. The industry was born with the introduction of conventional $x$-ray equipment, within a year of Roentgen's discovery of $X$ rays in 1896. By the early 1980s, six new technical subfields of the imaging industry had emerged, as listed in table 1.

The first expansion of the industry beyond conventional $x$-ray equipment occurred in the early twentieth century with the introduction of electro-

\footnotetext{
${ }^{6}$ Kogut does not report a distinction between acquisition by one of the parties to the joint venture and acquisition of the joint venture by a third party.
} 
Table 1

Diagnostic imaging industry technical subfields. ${ }^{\mathrm{a}}$

\begin{tabular}{llll}
\hline & \multicolumn{2}{l}{ Commercial introduction } & \\
\cline { 2 - 3 } Subfield & U.S. & Non-U.S. & $\begin{array}{l}1988 \text { U.S. sales } \\
\text { (\$ million) }\end{array}$ \\
\hline Conventional $x$-ray & 1896 & 1896 & 600 \\
Electrodiagnostic & 1911 & 1911 & 200 \\
Nuclear medical & 1954 & c. 1956 & 200 \\
Ultrasound & 1957 & c. 1954 & 500 \\
Computed tomography & 1973 & 1972 & 500 \\
Magnetic resonance & 1980 & 1978 & 500 \\
Digital radiography & 1981 & 1981 & 400 \\
\hline
\end{tabular}

${ }^{2}$ Sales estimates are reported in constant 1988 dollars ( $\$$ million), based on the Producer Price Index (PPI) deflator.

diagnostic instruments, including electrocardiographs and electroencephalographs. During the $1950 \mathrm{~s}$, commercial nuclear medical and ultrasonic imaging instruments were introduced to medical practice. Computed tomographic (CT) instruments were introduced during the early 1970s. Commercial nuclear magnetic resonance imaging (NMR or MRI) and digital radiographic imaging instruments were introduced in the early 1980s.

The emergence of new subfields involved considerable market and technical uncertainty [Hamilton (1982)]. Competition among alternate products and technical approaches, and uncertainty over clinical and market acceptance have typically been great for several years after the initial emergence of the subfield. For example, nuclcar medical and ultrasound imaging only achieved acceptance in the middle to late sixties, more than a decade after the products establishing these subfields first emerged, and did not diffuse rapidly until the $1970 \mathrm{~s}$. Although recently emerging subfields have tended to converge on a single technological paradigm more quickly, and have achieved market and clinical acceptance more rapidly, even these were characterized by several years of significant uncertainty.

The market for imaging equipment grew slowly during the first half of the century, then expanded rapidly following the introduction of the new imaging equipment during the 1950s and again as the U.S. medical market expanded during the 1970s. Rapid technical advancement of imaging quality, both from equipment in new subfields and improvements to instruments in established subfields, have spurred the growth. Annual imaging equipment sales grew from approximately $\$ 30$ million in the early 1950 s to about $\$ 3$ billion during the late 1980s.

Technical shifts in each emergent subfield can be characterized as being relatively low in transilience because, although the core technology in each case represented a significant innovation, the supporting assets required to commercialize the product were largely similar. For instance, many of the 
reputations, distributions and service systems, and incremental R\&D capabilities that were valuable in existing subfields have continued to be useful in emerging subfields. This factor and the sales potential of new subfields has led many industry incumbents to expand into new subfields. At the same time, the growth of the industry has attracted many new participants to the industry.

Although supporting assets have retained their value through each emergence of a new subfield, there has been some variation in the degree to which the utility carried through. Ultrasound and electrodiagnostic instruments, in particular, have required different distribution and service systems than products in the other technical subfields of the industry, because of differences in market segmentation. Conventional $x$-ray, nuclear imaging, CT, MRI, and digital radiographic instruments are sold primarily to hospital-based radiologists. Ultrasound and electrodiagnostic instruments, meanwhile, have traditionally been sold to other hospital-based medical specialists and to physicians in private practice. The ultrasound and electrodiagnostic subfields, therefore, represent relatively high-transilience cases relative to the other technical subfields of the imaging industry.

\subsection{Concepts and definitions}

The conduct of the study required that boundaries be defined for the geographic and product scope of the market and that levels of analysis be chosen. The geographic scope of the study was limited to the U.S. market, because diagnostic imaging cquipment distribution and service networks tend to be defined within national boundaries. Manufacturers of imaging systems used for human diagnostics within hospitals, outpatient clinics, and physician's private offices were included in the study, while producers of dental and veterinary imaging equipment were excluded. Also excluded were component manufacturers and firms that distributed other company's products without undertaking independent manufacture. The analysis was conducted at the parent-firm level of analysis, so that entry was recorded when an organizational subunit of a corporation, such as a division or subsidiary, first began to manufacture imaging systems for sale in the U.S. market.

In addition, it was necessary to identify forms of pre-entry interorganizational alliances commonly used in the imaging industry. An alliance was defined as a long-term cooperative agreement between an incumbent of the U.S. imaging industry and another commercial firm operating in a technical subfield of the industry. A pre-entry alliance, meanwhile, was defined as an alliance formed before an industry incumbent entered the subfield in which its partner was operating. Long term was defined as an agreement that involved more than a single transaction. Based on empirical frequency, two 
types of alliances were identified, distribution and know-how sourcing ventures.

Distribution alliances were agreements for an industry incumbent to distribute imaging systems manufactured by another firm, before the introduction by the incumbent of its own systems in the new technical subfield. A manufacturer of $x$-ray equipment, for example, might first distribute another firm's computed tomography system, and then undertake CT manufacture itself. A distribution alliance permits an incumbent to realize part of the value of its specialized distribution system in a new setting without undertaking the uncertainty of direct manufacturing entry. At the same time, such an alliance provides both access to technical know-how generated by another firm and an opportunity to learn about the market for the emerging product.

Know-how sourcing ventures, meanwhile, were cases in which an industry incumbent acquired technical capabilities from another firm before the incumbent's entry into a new subfield. Such alliances included joint ventures, minority equity investment by the incumbent, and long term licensing of technology from another firm. In other industries or at other times, other forms of alliances such as joint research would likely be found.

Because alliances commonly involve multiple motives and complex legal and organizational relationships, a conservative approach was adopted for the definition of alliances. Multiple sources were employed to verify all alliances. Where there was uncertainty on the nature of or motivation for the alliance, the case was discarded from the analysis. ${ }^{7}$

\subsection{Sample}

The data for this study were drawn from an extensive archival study of published and unpublished academic, industry, business, and government sources. The search was supplemented by interviews with industry and academic participants. The sample comprised all entrants to the nuclear imaging, ultrasound, computed tomographic, magnetic resonance, and digital radiographic subfields which had manufactured systems in any other subfield of the imaging industry before entering the new subfield. ${ }^{8}$ A plurality of the sample were firms with majority-ownership based in the United States, but incumbents based in Europe, Japan, and elsewhere were also included. In

\footnotetext{
${ }^{7}$ In two cases, the incumbent entered into both distribution and know-how sourcing alliances. Both of these cases were categorized as distribution alliances, on the basis of first occurrence. To test the impact of this categorization, the analysis was conducted with the two cases classified as know-how sourcing. The results were substantially the same, though the overall explanatory power was weaker.

${ }^{8}$ The subfields chosen are the five which have emerged since the $1950 \mathrm{~s}$, because comprehensive data for early entry into the $x$-ray and electrodiagnostic subfields was not available.
} 
Iable 2

Sample profile.

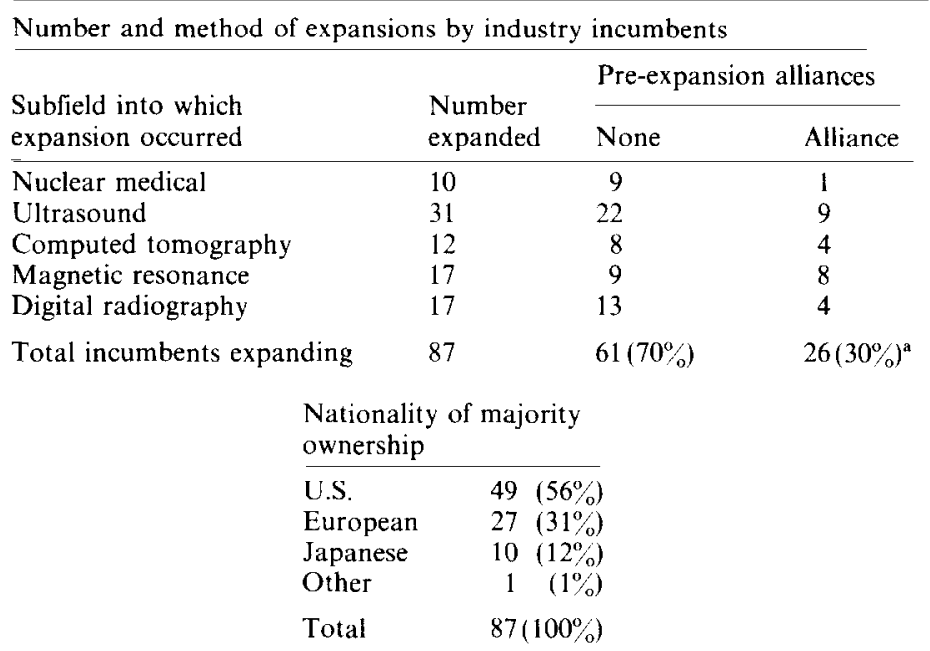

${ }^{a}$ Includes 15 distribution and 13 know-how alliances, which do not sum to total incumbents expanding after a pre-entry alliance (26) because two incumbents used both distribution and know-how alliances before expansion.

total, there were 87 entries by 45 incumbents into the 5 new subfields. Table 2 provides a profile of the sample.

\section{Hypotheses}

The earlier theoretical discussion leads to several testable hypotheses in the context of the diagnostic imaging industry. Imaging industry incumbents have faced significant collaborative incentives. They usually possess skills, resources and complementary assets such as manufacturing capability, distrihution systems, and service and maintenance organizations to offer potential alliance partners. The incentive for incumbents to collaborate is reinforced by the trend, as in many other industries, for advances in imaging technology to comc from a varicty of sources both within and outside the industry [Frost and Sullivan (1974, 1982); Foster (1986), Dosi (1988)]. The significant shifts of knowledge bases required to manufacture goods in new subfields and the rapid pace of obsolescence of core products in the imaging industry makes commitment to one particular technology, and limiting information access to in-house sources only, a high risk strategy [Mitchell and Singh (1990)].

One strategy for incumbents which wish to enter a new subfield is to acquire an earlier entrant. But the often disappointing results of outright 
purchases of small firms for their technological and innovative capabilities [Doz (1988)] has encouraged firms to enter into alliances as alternative channels for obtaining access to required information [Wachtler (1988)]. Alliances may be more suitable devices for incumbents to obtain market knowledge and technical know-how than either hierarchical or market means [Powell (1990)], particularly in the highly competitive and uncertain cnvironment of the health care industry [Pointer et al. (1988)]. Such alliances may be less likely to smother creative abilities and may reduce the costs and difficulties of direct governance below those imposed by outright acquisition [Williamson (1975)]. ${ }^{9}$ Pre-entry alliances between incumbents and other firms can therefore be expected to be a common feature of the imaging industry.

Hypothesis 1. Industry incumbents which expand into new technical subfields will frequently participate in pre-entry interorganizational alliances.

A strong incumbent faces strong collaborative incentives. Part of an incumbent's strength relates to its industry-specific characteristics. The stronger the industry-related market and technical position of an incumbent, the broader its supporting assets and the more it can offer potential allies. Therefore, it is likely to attract the most lucrative offers. Morecver, its strength provides the ability to dominate a successful partnership, making expansion via alliances particularly attractive to it. ${ }^{10}$ In addition, having the most assets committed to existing fields and possessing an established reputation, the strong incumbent also has the most to lose if standalone entry goes awry. In an industry characterized by high failure rates among entrants into new subfields [Mitchell (1991a)], the need for significant idiosyncratic investments [Hess (1987)], and high technical and market uncertainty [Hamilton (1982), Pointer et al. (1988)], there are particularly strong inducements for leading incumbents to enter via alliances.

In addition to industry-related attributes, an incumbent may be strong in terms of characteristics that are not specifically related to any one industry or sector. Greater financial resources, in particular, may allow a firm to undertake ventures that a resource-constrained business would not be able to initiate. We have no strong prior case for the differential impact of industryrelated strength and general strength on the tendency to engage in pre-entry alliances. Therefore, we will state the hypothesis simply in terms of strength,

\footnotetext{
${ }^{9}$ The relatively poor protection provided by patents and copyrights in the imaging industry [Frost and Sullivan $(1974,1982)]$ effectively increases the value of any information obtained from the ally, and provides yet another incentive for alliances.

${ }^{10}$ Despite the likelihood that the industry incumbent will eventually dominate a successful alliance, the possession of broad supporting assets will permit strong incumbents to attract partners who lack the ability to enter alone.
} 
but operationalize it in the analysis section as both industry and general strength so that we can empirically distinguish between the effects.

A strong incumbent also faces alliance disincentives, particularly the chance that a partially-controlled partner may damage the incumbent's current position through bad technical or strategic choices. On balance, however, we believe that the strongest incentives will favour collaborative arrangements. The combination of promising offers, the likelihood of dominating a successful alliance, the opportunity to reduce idiosyncratic investments and mediate market and technical risks, and the potential losses through standalone entry is likely to result in the strongest incumbents being over-represented among alliances.

Hypothesis 2. The stronger the position of an industry incumbent, the more likely it is to participate in a pre-entry alliance before expanding into a new subfield.

Contradictory forces also influence the use of alliances at different stages of subfield development. Firms which enter a new subfield before market and technical uncertainty have abated motives for early collaborative efforts. On the other hand, fewer potential partners with the necessary skills and resources to induce the incumbent to enter into a collaborative arrangement are available early in subfield history. Incumbents which choose early entry, therefore, may be forced to enter through standalone methods. Pre-entry alliances are likely to be associated with incumbents which undertake independent entry relatively late in the development of a new technical subfield.

Hypothesis 3. The later its expansion into a new technical subfield of an industry, the more likely an industry incumbent will participate in a preentry alliance.

Although the imaging industry has been characterized as having low transilience, we noted earlier that the value of ultrasound and electrodiagnostic support assets carried through only partially to the other technical subfields. In the Abernathy and Clark (1985) framework, incumbents expanding in to the ultrasound or electrodiagnostic subfields from the other subfields (or into the other subfields from these two subfields), would be undertaking 'architectural' innovation in applying new technology in new markets. These firms would have to develop their technical and product-related assets, as well as their supporting (i.e., market-related) assets in order to operate in the new subfield, a substantial challenge for any firms that tailored its capabili- 
ties for its existing operations [Nelson and Winter (1982), Hannan and Freeman (1977, 1984), Prahalad and Bettis (1987)]. In contrast, incumbents moving between nuclear medical, computed tomography, magnctic resonance and digital radiography would be applying new technology in essentially the same market segments, so that existing supporting assets tend to retain their value in the new subfields. These innovations represent lower transilience moves relative to architectural innovations.

This presents an incumbent of the ultrasound subfield which is considering entry into the computed tomography subfield with a relatively higher transilience adjustment than a firm expanding from the $x$-ray into the computed tomography subfield. The key differences between subfields in this respect lie not in their core technologies, which differ significantly, but in the transferability of the value of supporting assets. Supporting assets are more valuable for an incumbent moving between low transilience subfields than they are for a move between high transilience subfields. The more valuable these supporting assets in other subfields, the greater the attractiveness of the incumbent to its potential allies, and the greater the possibility of alliance. The less transferable these supporting assets, the less likely the alliance.

The disincentive will be particularly strong for distribution alliances, as the incumbent's specialized distribution and service resources will provide little value to a partner. Indeed, when the value of supporting assets does not carry over into a new subfield, an incumbent will be relatively unlikely to expand into it. For those incumbents which do expand into the new subfield, however, the incentive to undertake a pre-entry know-how sourcing alliances may be just as strong in the high as in the low-transilience case, because the need for core technical knowledge is just as great.

Hypothesis 4. (a) The more that a new technical subfield requires new supporting products, the less likely that an industry incumbent will participate in a pre-entry distribution alliance before expanding into the new subfield.

Hypothesis 4. (b) The degree to which a new technical subfield requires new supporting products will not be associated with participation by industry incumbents in pre-entry know-how sourcing alliances.

Because we are investigating entry in a geographic American market by both U.S. and foreign-based firms, it is possible that we will find nationalitybased propensities to undertake pre-entry distribution and know-how sourcing alliances. Foreign firms are sometimes viewed as being more likely to participate in alliances than American businesses. Japanese firms, in particular, have commonly used distribution and technical alliances to combine inhouse and external know-how, and have been observed to employ alliances 
as part of a gradual market entry strategy [Gerlach (1987), Kuhn (1989), Mitchell and Fiegenbaum (1990)]. ${ }^{11}$

Hypothesis 5. A majority American-owned incumbent is less likely than a majority foreign-owned incumbent to participate in a pre-entry alliance before expanding into a new technical subfield.

The industry incumbent member of an alliance represents only one end of a transaction. In addition to the incentives for incumbents to undertake collaborative ventures, there must be incentives for the partner. Although examination of these incentives is largely beyond the scope of this study, we will also address some of the motives for an incumbent's partner to undertake these ventures.

\section{Methods}

\subsection{Variables}

Dependent variables. Three variables recorded whether an industry incumbent which entered a new technical subfield of the diagnostic imaging industry had participated in a subfield-relevant alliance before its entry. The first variable noted whether the incumbent had distributed another firm's imaging systems before its entry into the new subfield. The second variable recorded whether the incumbent had used a know-how sourcing alliance before its entry. The third variable, a measure of all alliances, combined distribution with know-how sourcing alliances. The variances took the value of 1 if pre-entry alliance was employed and 0 if entry took place without a prior alliance.

Covariates. Independent variables were defined to test the predictions regarding nationality of majority ownership, lateness of independent entry, retention of the value of existing supporting assets, and incumbent strength. Table 3 presents summary statistics and the correlation matrix for the independent variables. A dummy variable categorization of incumbents as American or other was based on the country of origin of the majorityownership of the parent company.

The lateness of standalone entry was measured by the duration in years between the emergence of a subfield and the entry of the incumbent, with the count starting at one for an incumbent which entered during the first year of subfield history. On average, standalone entries tended to occur relatively

\footnotetext{
${ }^{11}$ Although we are examining expansion within the American diagnostic imaging equipment market, pre-entry distribution and know-how alliances, as we define them, may take place anywhere. A Japanese firm, for instance, might distributc in Japan a CT imaging system manufactured by a European corporation before undertaking its own manufacturing entry to the American market for CT instruments.
} 
lable 3

Summary statistics.

\begin{tabular}{lrrrrrrr}
\hline & \multicolumn{7}{c}{ Product-moment correlations $(N-87)$} \\
\cline { 5 - 9 } Independent variable & \multicolumn{1}{c}{ Mean (s.d.) } & 1 & 2 & 3 & 4 & 5 \\
\hline 1. Market share & 0.02 & $(0.03)$ & 1.00 & & & & \\
2. Corporate sales (log \$Million) & 5.70 & $(2.88)$ & 0.48 & 1.00 & & & \\
3. Years before entry & 10.93 & $(8.62)$ & -0.18 & -0.13 & 1.00 & & \\
4. High transilience & 0.41 & $(0.50)$ & -0.33 & -0.28 & 0.69 & 1.00 & \\
5. U.S. firm & 0.56 & $(0.50)$ & 0.11 & -0.34 & 0.05 & 0.22 & 1.00 \\
6. Number of previous alliances & 0.40 & $(0.88)$ & 0.66 & 0.39 & -0.12 & -0.28 & -0.02 \\
\hline
\end{tabular}

late after the emergence of the new subfields, with the average wait before entry being almost 11 years. In part, this figure speaks to the caution with which incumbents approach expansion. However, the average lateness of entry differed greatly across subfields: 10 years for nuclear medical imaging, 21 years for ultrasound, 5 years for computed tomography, 5.5 years for magnetic resonance imaging, and 3 years for digital radiography. These periods are consistent with the greater market uncertainty that accompanied the emergence of earlier subfields and the more rapid commercial establishment of the more recent subfields.

A $0-1$ measure of relative transilience was based on a firm's experience in the ultrasound or electrodiagnostic subfield. Entry into the ultrasound subfield by an industry incumbent lacking experience in the electrodiagnostic subfield was treated as high-transilience. Entry into any of the other four subfields (nuclear, CT, magnetic resonance, or digital radiography) by an incumbent with experience only in the ultrasound or electrodiagnostic subfield was also classed as high-transilience. Other cases were recorded as low-transilience.

An incumbent's strength was based on two measures, its total corporate sales and its imaging industry market share. Total sales, which were defined as constant dollar (1967 Producer Price Index) firm-wide sales in the year prior to an entry into a new subfield, are a measure of the resources available to a corporation. To taper the impact of very large sales values, the $\log$ value of dollar sales (expressed in millions) was used. Market share, which was defined as a firm's dollar-based industry-wide market share during the year before its entry into a new subfield, represents the industry-specific skills and supporting assets available to a firm. ${ }^{12}$

\footnotetext{
${ }^{12}$ Analyses were also carried out with a market scope variable, which recorded the proportion of imaging industry subfields in which a firm was participating during the year before its entry, but the measure did not produce independent information because of strong correlation with market share. A multiplicative interaction between share and scope, which emphasized the strength of firm's possessing both high industry share and scope, produced results similar to those obtained with the market share measure.
} 
The 87 entries into emerging subfields were accounted for by 47 incumbents and the 26 alliance entries by 17 incumbents. To control for idiosyncrasies of individual firms' alliance strategies and for organizational learning effects, an additional independent variable recorded the number of times that an entrant previously had employed a pre-entry alliance. We also recorded the number of previous entries, but the measure was too strongly correlated with several of the other variables to provide independent information.

\subsection{Statistical method}

Analysis for the substantive focus of the study was performed with logistic regression. At the onset, two alternative methods were available for the analysis, multinomial logit or conditional logit. The multinomial approach treats the three entry modes as independent choices (standalone, pre-entry distribution alliance, pre-entry know-how alliance). The conditional logit approach, meanwhile, models the entry decision as a nested 2-step process: The incumbent first decides whether to enter via an alliance; conditional on having chosen to do so, the firm then chooses the alliance type. We rejected the conditional logit approach because we do not believe that it accurately portrays the decision process, and adopted the multinomial logic model instead.

The basic argument underlying this research is that there are incentives for incumbents to enter emerging subfields through alliances in order to exploit cxisting capabilities or to overcome perceived deficiencies. If an incumbent decides to enter an emerging subfield through an alliance, the type of alliance it can employ is strongly influenced by its resources or deficiencies. If it has distribution-related specialized assets that it can exploit, and that its potential partner finds attractive, it will enter through a distribution alliance. If it lacks knowledge about the new subfield, it will enter through a knowhow sourcing alliance to overcome this shortcoming. Consequently the choice among alliance types is not nested or ordered, rendering the conditional logit model inappropriate. The entry decision was modeled as a single step selection between standalone entry, entry following a distribution alliance, or entry following a know-how sourcing alliance.

Analysis of the impact of the covariates on the method of entry was conducted by calculating a multinomial logistic regression equation of the form in eq. (1).

$$
\ln \left(P_{i} / P_{0}\right)=\alpha+\beta_{j} X_{j}
$$

where $P_{i}$ is the probability of an event occurring for the $j$ th case, which in this paper we define as a pre-entry distribution aliance $(i=1)$ or a pre-entry 
know-how sourcing alliance $(i=2) . P_{0}$, meanwhile, is the probability of standalone entry. Therefore $P_{i} / P_{0}$ represents the probability of entry through type of alliance $i$ over the probability of standalone entry.

For comparison and for concise reporting, we also estimated a binomial logit model of all-alliances versus standalone entry. This is particularly useful for examining effects that were predicted to have the same dircction of influence on the likelihood of employing both know-how and distribution pre-entry alliances, such as the lateness of entry variable. The model comparing all alliances against no alliances was run as a simple logit model, with standalone entry defined as the base case $(i=1$ for both distribution and know-how alliances).

The logistic transformation of the probability linearizes the relationship between the probability and the vector of covariates $X_{j}$, with $\beta_{j}$ representing the vector of coefficients and $\alpha$ representing the intercept. The estimates were obtained by using maximum likelihood routines of the LOGIT procedure of LIMDEP [Greene (1990)]. Further information regarding logistic regression can be found in Hanushek and Jackson (1977) and Maddala (1983).

\section{Results}

Table 2 demonstrates that, as predicted in Hypothesis 1, interorganizational alliances are frequently used by industry incumbents before their independent entry into new technical subfields of an industry. Of the 87 market entries by industry incumbents, 26 were preceded by at least one form of pre-entry collaboration, with 15 distribution and 11 know-how sourcing alliances. The fact that almost one in three incumbents chose to participate in a pre-entry alliance demonstrates the caution with which these incumbents approached the potential gains and risks associated with standalone entry. By implication, alliances offer considerable potential access to market and technological information, since incumbents are unlikely to enter into collaborative arrangements if the expected benefits of such arrangements were marginal. Nonetheless, about two-thirds of the expanding incumbents chose not to participate in a pre-entry alliance. The tests of the remaining hypotheses help identify conditions under which alliances are more or less likely.

The results of the tests of Hypotheses 2-5 are presented in table $4 .{ }^{13}$ Consistent with the raw frequency of alliances, the negative and significant

\footnotetext{
${ }^{13}$ For conservativeness, we report the default significance of the coefficients in table 4 on the basis of two-tailed tests. Given that we have predicted directions for the effects of the variables, however, interpretation on the basis of one-tailed tests is appropriate. Hence, coeflicients which are reported as significant at the two-tailed 0.10 level are significant at the 0.05 level relative to specific predictions.
} 
Table 4

Logistic regression analyses of the tendency to participate in distribution and know-how sourcing alliances before expansion ( $N=87$, standard errors in parentheses). ${ }^{\mathbf{a}}{ }^{\mathbf{b}}$

\begin{tabular}{|c|c|c|c|}
\hline \multirow[b]{2}{*}{ Variable } & \multicolumn{2}{|c|}{$\begin{array}{l}\text { Multinomial logit: } \\
\text { Alliance-type versus no alliance }\end{array}$} & \multirow{2}{*}{$\begin{array}{l}\text { Binomial logit } \\
\text { All } \\
\text { alliances (26) }\end{array}$} \\
\hline & $\begin{array}{l}\text { Distribution } \\
\text { alliances (15) }\end{array}$ & $\begin{array}{l}\text { Know-how } \\
\text { alliances (11) }\end{array}$ & \\
\hline Intercept & $\begin{array}{l}-2.435^{* *} \\
(1.207)\end{array}$ & $\begin{array}{l}-5.349^{* * *} \\
(1.615)\end{array}$ & $\begin{array}{l}-2.940^{* * *} \\
(1.050)\end{array}$ \\
\hline Industry market share & $\begin{array}{c}28.651^{*} \\
(17.102)\end{array}$ & $\begin{array}{c}17.821 \\
(19.213)\end{array}$ & $\begin{array}{r}21.836 \dagger \\
(14.667)\end{array}$ \\
\hline Corporate size (log sales) & $\begin{array}{c}-0.013 \\
(0.156)\end{array}$ & $\begin{array}{c}0.275 \dagger \\
(0.177)\end{array}$ & $\begin{array}{c}0.121 \\
(0.126)\end{array}$ \\
\hline Lateness of entry & $\begin{array}{l}0.151^{* *} \\
(0.061)\end{array}$ & $\begin{array}{l}0.153^{* *} \\
(0.071)\end{array}$ & $\begin{array}{l}0.150^{* * *} \\
(0.053)\end{array}$ \\
\hline Subfield transilience & $\begin{array}{l}-2.504^{* *} \\
(1.193)\end{array}$ & $\begin{array}{r}-2.019 \dagger \\
(1.339)\end{array}$ & $\begin{array}{l}-2.241^{* *} \\
(1.005)\end{array}$ \\
\hline U.S. ownership & $\begin{array}{r}-0.247 \\
(0.807)\end{array}$ & $\begin{array}{l}1.540^{*} \\
(0.925)\end{array}$ & $\begin{array}{c}0.541 \\
(0.647)\end{array}$ \\
\hline Previous alliances & $\begin{array}{c}-0.367 \\
(0.417)\end{array}$ & $\begin{array}{r}-0.837 \dagger \\
(0.610)\end{array}$ & $\begin{array}{r}-0.518 \dagger \\
(0.387)\end{array}$ \\
\hline $\begin{array}{l}\text { Model } \chi^{2}(\mathrm{df}) \\
\text { Overall fit (Alliance fit) }\end{array}$ & \multicolumn{2}{|l|}{$\begin{array}{l}21.3(12)^{* *} \\
78 \%(4 / 15 ; 4 / 11)\end{array}$} & $\begin{array}{l}16.5(6)^{* *} \\
77 \%(10 / 26)\end{array}$ \\
\hline
\end{tabular}

intercepts of the models for distribution, know-how, and all alliances indicate that, on average, alliances were not used. Controlling for that factor, the signs and significance of the coefficients are largely consistent with the predicted effects. Moreover, each of the models shown has significant explanatory power, demonstrated by the significance of the model $\chi^{2}$ statistics. ${ }^{14}$

Although the overall predictive fit of each model is high ( $77 \%$ of the cases), only 27 to $38 \%$ of the active events, that is, entry through alliances, could be predicted. The relative weakness of the models reflects the small number of distribution and know-how alliances included in the data. Because the research was not geared towards the development of a comprehensive predictive model, the relatively low prediction of active events was not deemed to be a major problem for the study. Instead, our primary interest lies in the reported tests of individual hypotheses.

Hypothesis 2 predicted that strong industry incumbents would be more

\footnotetext{
${ }^{14}$ Twice the difference between the loglikelihood values of the full and intercept-only models is distributed as a $\chi^{2}$ statistic with degrees of freedom equal to the difference in the number of parameters estimated.
} 
likely to participate in pre-entry alliances. The results reported show that one measure of incumbent strength, market share, is associated with participation in distribution alliances and the second measure of strength, total corporate sales, is marginally associated with participation in know-how alliances. The association between market share and distribution probably occurs because of the broad distribution and service systems possessed by high sharc imaging industry firms. The relationship between corporate size and knowhow alliances, meanwhile, is likely to be the result of large corporations having more resources available with which to undertake minority investment, joint ventures, and other such alliances requiring outlay of resources. In the all-alliance model, the effect of incumbent strength is most strongly associated with the market share variable. ${ }^{15}$

Hypothesis 3 predicted that entrants which enter later would be more likely to participate in pre-entry alliances. The expected result is shown in table 4 for distribution, know-how, and all alliances. Firms which choose to enter early in the history of a new subfield accepted the uncertainty of standalone entry, possibly because they had fewer potential partners.

Hypotheses 4(a) and 4(b) predicted that when incumbents expand into subfields which require new supporting products they will be less likely to participate in pre-entry distribution alliances, but just as likely to participate in pre-entry know-how alliances. The expected results were found for the distribution case, as shown by the negative coefficient of the subfield transilience variable in table 4. Having less to offer potential partners, industry incumbents are less likely to distribute another manufacturer's goods before carrying out independent entry into high-transiliencc subficlds.

However, contrary to the Hypothesis 4(b), firms making high transilience moves also proved to be marginally less likely to enter into know-how sourcing alliances than those making low transilience moves, although the strength of the effect is slightly less than in the know-how sourcing case. It is possible that these firms were less attractive allies, relative to low transilience incumbents, and therefore attracted fewer offers. Despite the greater need for these firms to enter into alliances, the relative unattractiveness of these incumbents may have resulted in fewer alliances being effected.

Another aspect of the new supporting asset case is highlighted by the high correlation between the transilience and years before entry variables, as noted in table 3. When new supporting assets must be acquired, entry tends to take place later than when the value of existing supporting assets carries over to new core products, indicating that the relative absence of supporting

\footnotetext{
${ }^{15}$ Models that omitted the size variable produced similar results, although with weaker predictive power. The nonsignificant positive relationship between market share and know-tiow alliances become significant in the reduced model. This result follows from the positive correlation between market share and size.
} 
assets is a constraint for firms contemplating entry into related subfields. This again speaks to the caution with which firms expand, even when innovation takes place within the broadly-defined industry in which the firm already participates.

Hypothesis 5, which postulates that American-owned incumbents will be less likely than forcign-owncd incumbents to participate in alliances, was rejected. The expected negative coefficient was found for distribution alliances, but at a non-significant level, so that foreign-owned incumbents appear to be at least as likely as domestic firms to attract distribution alliance partners on the basis of their supporting assets. Contrary to Hypothesis 5, however, U.S. firms were more likely to enter into know-how alliances than other firms. With more medical equipment sector manufacturers based in the U.S. than in any other country [Dummer and Robertson (1966), American Hospital Association (1966), Directory Systems, Inc. (1986), Hale and Hale (1986)], it may be that an American ownership base provides better information about potential partners. ${ }^{16}$

Finally, control for the number of previous entries into emerging subfields that were preceded by alliances was marginally significant for know-how sourcing alliances, but not for distribution alliances. The negative sign of the effect is intriguing. It appears that firms which have experience with knowhow alliances are slightly less likely to use them again, possibly because of dissatisfaction with the results of past alliances. This result must be interpreted cautiously, owing to the strong correlation between the previous entries and market share variables. The previous alliance result implies that, among firms with large market shares, experience with previous know-how alliances tends to reduce the likelihood of pursuing another alliance.

The general weakness of the previous alliance results is also interesting. There appears to be relatively little firm-specific rigidity of alliance behaviour. Instead, the incumbents in the sample tended to vary their alliance strategies on the basis of product and subfield characteristics. This may be due to organizational and external factors such as the limited capacity of the firm's channels, its marketing and corporate strategies which may impose product-market consistency requirements, and constraints imposed by the allied firm which may set limits on the number of lines that its incumbent partner may distribute.

Although the focus of this paper is on the incentives for industry incumbents to undertake pre-entry alliances, we found it informative to investigate the partners to the alliances. Our estimate is that the primary purpose for the partner in the distribution alliances was entering a foreign market, about half of the entries being into the U.S. and half being Europe

\footnotetext{
${ }^{16}$ In addition, contingency table tests revealed no significant differences between use of alliances by Japanese and European-owned firms.
} 
or Japan. ${ }^{17}$ The sole purpose for the know-alliances, from a partner's point of view, was expansion in the industry.

We also investigated whether the partners and incumbents in the 26 alliances continued to participate in the industry at the end of the study, finding a bias in favour of incumbent survival. Only 9 partners remained, while 15 incumbents continued to participate. (In only 3 cases did the partner survive and the incumbent exit, while the converse occurred in 9 cases.) The only type of alliance which tended to be associated with partner survival was market entry into the United States, where 4 of 5 partners continued to participate.

\section{Discussion and conclusion}

Most of the predictions presented in this paper have been supported, although sometimes at marginal levels of statistical significance. Strong incumbents are more likely than weak players to participate in pre-entry interorganizational alliances, with high market share being associated with distribution alliances and larger corporate size with know-how sourcing alliances. Similarly, later entrants are more likely to participate in pre-entry alliances. When major changes are required to supporting assets, incumbents are less likely to participate in distribution alliances and, opposite our expectations, in know-how sourcing alliances. Contrary to conventional wisdom (and our prediction), American firms appear to be no less likely than their foreign-owned competitors to distribute another manufacturer's product before undertaking independent entry and are more likely to engage in a preentry know-how sourcing alliance.

These results provide two main contributions. First, empirical support has been provided for the claim that a firm's possession of key supporting assets will influence its strategy as it attempts to realize the returns from innovation [Teece (1986), Clark (1987)]. We have shown that alliance strategy will vary, depending on an industry incumbent's prior strength and on the disruption to the value of existing supporting assets. The relevance of Abernathy and Clark's (1985) conceptual transilience map has been demonstrated. The results are particularly strong owing to the inclusiveness of our sampling procedure - we compare cases in which alliances have been undertaken to those in which they were not, rather than studying only cases in which alliances have been formed and so risking sample selection bias. The results are robust, given the few degrees of freedom available.

Much further work remains to explore the supporting assets issue. For instance, the concept of supporting assets usefulness could be applied to

\footnotetext{
${ }^{17}$ The incumbent members of the foreign entry alliances, which by definition already participated in the U.S. imaging industry before entering into the alliance, subsequently expanded into the U.S. market for the new goods.
} 
investigating diversification moves - seemingly unrelated diversification could be explained by, or evaluated against, the criteria of core and supporting assets similarity. Coupling supporting asset value with related concepts of strategic variety [Prahalad and Bettis (1987)], technological discontinuities [Tushman and Anderson (1986)], and technological paradigms [Dosi (1982)] may improve explanation of the strategy and performance of diversifying firms.

The second contribution is to the emerging literature on interorganizational alliances. The results show that collaborative ventures are an important means employed by some types of incumbents to test the technical and market waters of emerging subfields, prior to their full entry as systems manufacturers. This appears to be a rational strategy for leading incumbents, allowing them to leverage their specialized assets and gain access to market and product information, while spreading risks in uncertain conditions. The general pattern of results provides a rational perspective of alliance between firms.

The results also raise welfare implications. Contrary to the often unfavorable portrayal of firms and managers engaging in power building and market constraint through interorganizational arrangements [Pfeffer and Salancik (1978)], the results are consistent with an interpretation of relatively efficient risk reduction and know-how acquisition. Access to an incumbent's distribution system or contribution by an incumbent of minority investment may increase the ability of a new entrant to participate in an emerging field. Such entry may well promote competition, technological innovation, and development within the field. At the same time, participation by the incumbent may help provide legitimacy for the fledgling field, and so provide an umbrella for innovative industry newcomers. This interpretation is limited by the narrow scope of the present study; clearly, the area merits further research.

The study has necessarily narrow limits, largely imposed by its 30 year retrospective collection of data. Many environmental and firm specific factors which influence the decision to participate in alliances have not been addressed in this paper. These include an incumbent's broad corporate strategy, its performance, the amount of slack resources available, effectiveness of internal $\mathrm{R} \& \mathrm{D}$, and perceptions of its management, as well as environmental factors such as the size and growth rates of the existing and ncw subficlds and the competitiveness of the industry. These variables could beneficially be incorporated into future research. Moreover, it would be useful to contrast this study with cases when incumbents employed pre-entry alliances and then chose not to enter. It would also be interesting to study the post-entry performance of the firms following standalone expansion and pre-entry alliance strategies. Survival and other performance differentials would provide useful information on the efficacy of the different entry mechanisms, and help clarify the role that specialized assets play in the 
choice among entry methods. Finally, research integrating characteristics of incumbents' allies would provide a fuller picture of the factors which influence use of alliances.

Although limited in its scope, the results of the study are important. We have described several of the key implications above. In addition, part of the substance of the findings relates to the potential that they will differ in future environments, because there is no assurance that all the factors identified in this retrospective study will have the same influence in the future. In particular, the tendency to avoid participation in alliances early in the development of a new subfield may be a relic of the past. The U.S. market for diagnostic imaging devices is facing the same increase in global competition that is occurring in most other industrial sectors. With the rise of new competitors, leading incumbents may be forced to enter new subfields more quickly than in the past [Mitchell (1989)]. Incumbents that rely on standalone entry in conditions of high technical uncertainty may well face serious competitive disadvantages, relative to entrants that combine internal development with interorganizational alliances [Pointer et al (1988), Hamel et al. (1989), Powell (1990)]. Thus, firms which hope to prosper in competitive environments may have to seek out alliance partners long before technical and market uncertainties have subsided. Interorganizational alliances will continue to be important, and new skills will have to be acquired in order to use them to prosper.

\section{References}

Abernathy, William J. and Kim B. Clark, 1985, Innovation: Mapping the winds of creative destruction, Research Policy 14, 3-22.

Abernathy, William J. and James M. Utterback, 1978, Patterns of industrial innovation, Technology Review 80, 97-107.

American Hospital Association, 1966, Guide issue, hospitals, Journal of the American Hospital Association 40, Aug.

Astley, W. Graham and Richard A. Brahm, 1989, Organizational designs for post-industrial strategies: The role of interorganizational collaboration, in: Charles C. Snow, ed., Strategy, organization design, and human resource management (JAI, Greenwich) 233-270.

Barney, Jay, 1986, Strategic factor markets: Expectations, luck, and business strategy, Management Science 32, no. 10, 1231-1241.

Clark, Kim, 1987, Investment in new technology and competitive advantage, in: David J. Teece, ed., The competitive challenge (Ballinger, Cambridge, MA) 59-81.

Clarke, Christopher and Kieron Brennan, 1988, Allied forces, Management Today, Nov., $128-131$.

Conner, Kathleen Reavis, 1988, Strategies for product cannibalism, Strategic Management Journal 9, 9-26.

Contractor, Farok J. and Peter Lorange, 1988, Competition vs. cooperation: A benefit/cost framework for choosing between fully owned investments and cooperative relationships, Management International Review 28, 5-18.

Cooper, Arnold C. and Dan Schendel, 1976, Strategic responses to technological threats, Business Horizons, Feb., 61-69.

Dasgupta, Partha and Joseph Stiglitz, 1980, Industrial structure and the nature of innovative activity, Economic Journal 90, 266-293. 
Directory Systems, Inc., 1986, Medical device register: Volume 2-International (Directory Systems, Inc., Stamford, CT).

Dosi, G., 1988, Sources, procedures and microeconomic effects on innovation, Journal of Economic Literature 26, 1120-1230.

Dosi, G., 1982, Technological paradigms and technological trajectories, Research Policy 11, 147-162.

Doz, Yves, 1988, Technology partnerships between larger and smaller firms: Some critical issues, International Studies of Management and Organization 17, 3-57.

Dummer, G.W.A. and J. Mackenzie Robertson, eds., 1966, Medical electronics equipment, 19661967 (Pergamon Press, Oxford).

Ford, David, 1985, The management and marketing of technology, in: Robert Lamb and Paul Shrivastava, eds., Advances in strategic management, Vol. 3 (JAI, Greenwich) 103-134.

Foster, Richard, 1986, Innovation: The attacker's advantage (Summit Books, New York).

Frost and Sullivan, Inc., 1974, Medical diagnostic equipment market (Frost and Sullivan, New York).

Frost and Sullivan, Inc., 1982, Medical ultrasound imaging equipment markets in the U.S. (Frost and Sullivan, New York).

Gerlach, M., 1987, Business alliances and the strategy of the Japanese firm, California Management Review 30, no. 1, 126-142.

Gilbert, Richard and David Newberry, 1982, Preemptive patenting and the persistence of monopoly, American Economic Review 72, 514-526.

Greene, William E., 1988, LIMDEP user's manual, Version 5 (William E. Greene, New York).

Gross, Thomas and John Neuman, 1989, Strategic alliances vital in global marketing, Marketing News 23, no. 13, 1-2.

Hale, Adeline B. and Arthur B. Hale, 1986, The medical aid and healthcare marketplace guide (International Bio-Medical Information Service, Miami, FL).

Hamel, Gary, Yves L. Doz and C.K. Prahalad, 1989, Collaborate with your competitors - and win, Harvard Business Review 67, no. 1, 133-139.

Hamilton, Betty, ed., 1982, Medical diagnostic imaging systems: Technology and applications (F \& S Press, distributed by Ballinger, Cambridge, MA).

Hamilton, George, 1985, Managing by acquisition, Management Today 61, May, 145-148.

Hannan, M.T. and J.H. Freeman, 1977, The population ecology of organizations, American Journal of Sociology Review 82, Mar., 929-964.

Hannan, M.T. and J.H. Freeman, 1984, Structural inertia and organizational change, American Journal of Sociology 89, 929-964.

Hanushek, Eric A. and John E. Jackson, 1977, Statistical methods for social scientists (Academic Press, New York).

Harrigan, Kathryn Rudie, 1985a, Strategic flexibility: A management guide for changing times (Lexington Books, Lexington, MA).

Harrigan, Kathryn Rudie, 1985b, Strategies for joint ventures (Lexington Books, Lexington, MA).

Harrigan, Kathryn Rudie, 1987, Strategic alliances: Their new role in global competition, Columbia Journal of World Business 22, no. 2, 67-89.

Hess, Thomas P., 1987, After hillinn-dollar stampede comes day of reckoning in MR, Diagnostic Imaging 9, 129-139.

Hitt, Michael A. and R. Duane Ireland, 1985, Corporate distinctive competence, strategy, industry and performance, Strategic Management Journal 6, 273-293.

Jewkes, John, David Sawyers and Richard Stillerman, 1958, The sources of invention (Macmillan, London).

Jorde, Thomas M. and David J. Teece, 1989, Competition and cooperation: Striking the right balance, California Management Review 31, no. 3, 25-37.

Katz, Michael L. and Carl Shapiro, 1987, R\&D rivalry with licensing or imitation, American Economic Review 77, 402-420.

Kirkpatrick, E.M., ed., 1983, Chambers 20th century dictionary (Cambridge University Press, Cambridge).

Knight, Frank, 1922, Risk, uncertainty, and profit (Harper and Row, New York). 
Kogut, Bruce, 1988, Joint ventures: Theoretical and empirical perspectives, Strategic Management Journal 9, 319-332.

Kogut, Bruce, 1989, The stability of joint ventures: Reciprocity and competitive rivalry, Journal of Industrial Economics 38, no. 2, 183-198.

Kuhn, Robert Lawrence, 1989, Japanese-American business alliances, Journal of Business Strategy 10, no. 2, 51-53.

Leonard-Barton, Dorothy, 1985, Experts as negative opinion leaders in the diffusions of technological innovation, Journal of Consumer Research 11, Mar., 914-926.

Levin, Richard C., Alvin K. Klevorick, Richard R. Nelson and Sydney G. Winter, 1988, Appropriating the returns from industrial R\&D, Discussion paper no. 862 (Cowles Foundation for Research in Economics, Yale University, New Haven, CT).

Lieberman, Marvin B. and David B. Montgomery, 1988, First-mover advantages, Strategic Management Journal 9, 41-58.

Maddala, G.S., 1983, Limited-dependent and qualitative variables in econometrics (Cambridge University Press, Cambridge).

Mansfield, Edwin, Mark Schwartz and Samuel Wagner, 1981, Imitation costs and patents: An empirical study, Economic Journal 91, 907-918.

Mitchell, Will, 1991a, Dual clocks: Entry order influences on industry incumbent and newcomer market share and survival when specialized assets retain their value, Strategic Management Journal, forthcoming.

Mitchell, Will, 1991b, Using academic technology: Transfer methods and licensing incidence in the commercialization of American diagnostic imaging equipment research, 1954-1988, Research Policy (forthcoming).

Mitchell, Will, 1989, Whether and when? Probability and timing of incumbents' entry into emerging industrial subfields, Administrative Science Quarterly 34, 208-230.

Mitchell, Will and Avi Fiegenbaum, 1990, Japanese forays into the American medical diagnostic imaging pay off, Journal of Applied Manufacturing Systems, 59 63.

Mitchell, Will and Kulwant Singh, 1990, Death of the lethargic: Effects of expansion into new technical subfields of an industry on survival in an a firm's base business, Working paper (University of Michigan, Ann Arbor, MI).

Mowery, David C., 1983, Innovation, market structure, and government policy in the American semiconductor electronics industry: A survey, Research Policy 12, 183-197.

Nelson, R.R. and S.G. Winter, 1982, An evolutionary theory of economic change (Harvard University Press, Cambridge, MA).

Pfeffer, Jeffrey and Phillip Nowak, 1976, Joint ventures and interorganizational interdependence, Administrative Science Quarterly 21, 398-418.

Pfeffer, Jeffrey and Gerald R. Salancik, 1978, The external control of organizations (Harper \& Row, New York).

Phillips, Almarin, 1966, Patents, potential competition and technical progress, American Economic Review 56, 301-310.

Pointer, Dennis, D., James W. Begun and Roice D. Luke, 1988, Managing interorganizational dependencies in the new health care marketplace, Hospital and Health Services Administration 33, 167-177.

Powell, Walter W., 1990, Neither market nor hierarchy: Network forms of organization, Research in Organizational Behavior 12, 295-336.

Prahalad, C.K. and R.P. Bettis, 1987, The dominant logic: A new linkage between diversity and performance, Strategic Management Journal 7, 485-501.

Ramanujam, Vasudevan and P. Varadarajan, 1989, Research on corporate diversification: A synthesis, Strategic Management Journal 10, 523-551.

Reinganum, Jennifer F., 1983, Uncertain innovation and the persistence of monopoly, American Economic Review 73, 741-748.

Reinganum, Jennifer F., 1985, Innovation and industry evolution, Quarterly Journal of Economics, 100, no. 1, 81-99.

Rumelt, Richard P., 1974, Strategy, structure and economic performance (Division of Research, Harvard University, Boston, MA).

Schumpeter, Joseph A., 1975, Capitalism, socialism and democracy (Harper \& Row, New York). (Originally published in 1942 by Harper \& Brothers) 
Teece, David J., 1981, The market for know-how and the efficient international transfer of technology, Annals of the American Academy of Political and Social Science 458, 81-96.

Teece, David J., 1986, Profiting from technological innovation: Implications for integration, collaboration, licensing and public policy, Research Policy 15, 285-305.

Teece, David J., Gary P. Pisano and Michael V. Russo, 1988, Joint ventures and collaborative arrangements in the telecommunications equipment industry, in: David Mowery, ed., International collaborative ventures in U.S. manufacturing (Ballinger, Cambridge, MA).

Tushman, Michael L. and Philip Anderson, 1986, Technological discontinuities and organizational environments, Administrative Science Quarterly 31, 439-465.

United States Supreme Court, 1964 Brown Shoe Co. v. United States, 370 U.S. 294.

Wachtler, Howard, S., 1988, Minority investments: Outposts of new technology, Mergers and Acquisitions 22, no. 4, 56-58.

Williamson, Oliver E., 1975, Markets and hierarchies: Analysis and antitrust implications (Free Press, New York).

Williamson, Oliver E., 1985, The economic institutions of capitalism: Firms, markets, relational contracting (Free Press, New York).

Williamson, Oliver E., 1988, Technology and transaction costs economics: A reply, Journal of Economic Behavior and Organization 10, 355-363. 